\title{
HUMAN OCCUPATION AND THE ENVIRONMENT DURING THE HOLOCENE IN THE RIVER CAUCA VALLEY, COLOMBIA. THE EVIDENCE FROM PALEOBOTANY AND FROM SOIL STUDIES*
}

\author{
OCUPACIONES HUMANAS Y EL MEDIO AMBIENTE DURANTE EL HOLOCENO \\ EN EL VALLE DEL RÍO CAUCA, COLOMBIA: LA EVIDENCIA DE LA \\ PALEOBOTÁNICA Y DE LA LITOLOGÍA
}

\author{
Neil Duncan ${ }^{a}$, Marianne Cardale Schrimpff ${ }^{b}$, Ana Maria Groot ${ }^{c}$, Pedro Botero ${ }^{d}$, \\ Alejandra Betancourt ${ }^{e}$, Juan Carlos Berrio ${ }^{f}$
}

\begin{abstract}
This paper summarises the results of on-going research on the valley floor by a multidisciplinary team of archaeologists and specialists in soils, pollen and phytoliths. The research project is designed to chart the history of human occupation of this complex and frequently flooded area during the Holocene and the interaction between this environment and the human population. In the mountains surrounding much of the upper and central Cauca valley there is a gap in our knowledge of human occupation of a thousand years and more with the most recent dates for preceramic sites in the third millennium B.C.; furthermore these later sites appear to be far less numerous than those known from earlier in the Holocene. This "archaeological silence" comes to an end about 700 B.C., by which time the area was inhabited by established farmers with sophisticated pottery. The period of silence is precisely when we would expect to find evidence for early Formative activity in the area, including an intensification of horticulture. Project results, so far, include evidence for local climatic fluctuations with wetter and drier periods, tentative evidence (burning) for human disturbance of the environment from very early in the Holocene (late IXth millennium B.C.) and firm paleobotanical evidence from one or probably two sites for cultivation (maize and arrowroot) associated with burning or other forms of disturbance of the vegetation within the period of "archaeological silence". Although no artefacts from this period have been found so far, a considerable number of sites were located from the late Formative period (Ilama and its daughter culture, Yotoco), testifying to a much more intensive occupation of the valley floor and its floodlands at this time than had been documented previously.
\end{abstract}

Key words: archaeology, environment and culture, Cauca Valley, Colombia.

Este trabajo resume los resultados de investigaciones en curso en el valle del río Cauca por un equipo multidisciplinario de arqueólogos y especialistas en suelo, polen y fitolitos. El proyecto de investigación está diseñado para estudiar la historia de la ocupación humana de esta área compleja frecuentemente inundada durante el Holoceno y la interacción entre el medio ambiente y la población humana. En las montañas que rodean gran parte del valle del Cauca medio y superior hay un vacío de más de mil años en nuestro conocimiento sobre las ocupaciones humanas de acuerdo con los fechados más recientes de los sitios precerámicos en el tercer milenio antes de Cristo; además, estos últimos sitios parecen ser mucho menos numerosos que aquellos conocidos anteriormente en el Holoceno. Este "silencio arqueológico" parece terminar hacia el 700 d.C., cuando el área fue ocupada por agricultores con cerámica sofisticada. El período de silencio es precisamente cuando pudiéramos haber esperado encontrar evidencias de actividad del Formativo temprano incluyendo la intensificación de la horticultura. Los resultados del proyecto hasta el momento evidencian fluctuaciones climáticas locales con periodos húmedos y secos, evidencias tentativas de alteración del medio ambiente (quemazones) desde muy temprano en el Holoceno (última parte del IX milenio a.C.) y evidencias paleobotánicas concretas de uno o dos sitios probables de cultivos (maíz y cocurito) asociado a quemas u otras formas de disturbación de la vegetación en el período del "silencio arqueológico". Aunque hasta el momento no se han encontrado artefactos correspondientes a este período, un número considerable de sitios del período Formativo tardío (Ilama y su hija cultural Yotoco) testifican como correspondiente a una ocupación mucho más intensiva en el piso del valle y sus zonas de inundación en este tiempo de lo que ha sido previamente documentado.

Palabras claves: arqueología, medio ambiente y cultura, valle del río Cauca, Colombia.

* Paper presented to the symposium "Archaeology, Paleoclimatic Models And Human Interaction In Latin America". LIV Congress of Americanists.Vienna, 15th-20th July, 2012.

a University of Missouri, Department of Anthropology, Research Specialist, Paleoethnobotany Laboratory, Columbia, Estados Unidos. Correo electrónico: neilandrewduncan@gmail.com

b Asociación Pro Calima para la Investigación Arqueológica, Bogotá, Colombia. Correo electrónico: marianne@ procalima.org

c Universidad Nacional de Colombia, Departamento de Antropología, Bogotá, Colombia. Correo electrónico: amgrootd@unal. edu.co

d Agrólogo, Investigador Independiente, Bogotá, Colombia. Correo electrónico: guiaspedro@gmail.com

e Universidad Nacional de Colombia, Instituto de Ciencias Naturales, Estudiante de Doctorado en Ciencias - Biología, Bogotá, Colombia. Correo electrónico: abetancourtaw@gmail.com

f Universidad de Leicester, Departamento de Geografía, Lecturer in Physical Geography, Reino Unido. Correo electrónico: jcb34@le.ac.uk 
This paper summarises the results of on-going research on the upper Cauca valley floor by a multidisciplinary team of archaeologists and specialists in soils, fossil pollen and phytoliths. The project, initiated in the autumn of 2008, is designed to chart the history of human occupation of this alluvial valley during the Holocene and the interaction between the human population and the environment.

For this more information on changes in climate and vegetation during this period is essential. Environmentally the area appears to have been extremely dynamic and preliminary interpretations of the evidence suggest that there was a very wet period at the beginning of the Holocene, followed by a prolonged drier period with fluctuations. The meandering course of the river Cauca produced numerous ox-bow lakes which would have been prime settlement sites while, on the down side, extensive flooding constituted an ever-present hazard. Additional problems were provided by the volcanoes, active in the Central Cordillera, and there is evidence for ash falls and for catastrophic quantities of this material washed into the area of study by tributaries of the river Cauca. It is vital to take all these conditions into account when assessing the region from the point of view of its attractions for human settlement in the early and middle Holocene.
In such a dynamic environment, finding human settlements and sites through traditional survey methods is nearly impossible, therefore this project utilized sediment coring to find well-preserved ancient soil horizons that would have been conducive to human settlement and utilization in the past. Phytoliths, pollen, and sedimentology studies of these buried sediments provide evidence for human activity in the floodplain of the Cauca valley from early in the Holocene.

For part of its upper course, the river Cauca runs through a broad, alluvial valley. slightly over 200 $\mathrm{km}$ long (from the towns of Timba in the south to near La Virginia, in the Departamento of Risaralda in the north) with an average width of between 15 and $30 \mathrm{~km}$. (Sandoval y Ramírez 2005: 21, Mapa en relieve de la Republica de Colombia, IGAC 1980). The river is navigable for most of this stretch and has provided a very important communication route for centuries and, probably, millennia. At the same time the valley has been open to communications and influences from the mountain ranges on either side, the Western and Central Cordilleras. The alluvial soils and volcanic ash make it one of the most fertile areas in Colombia while the river itself and its surrounding lakes and marshes are, even today, home to very large populations of fish

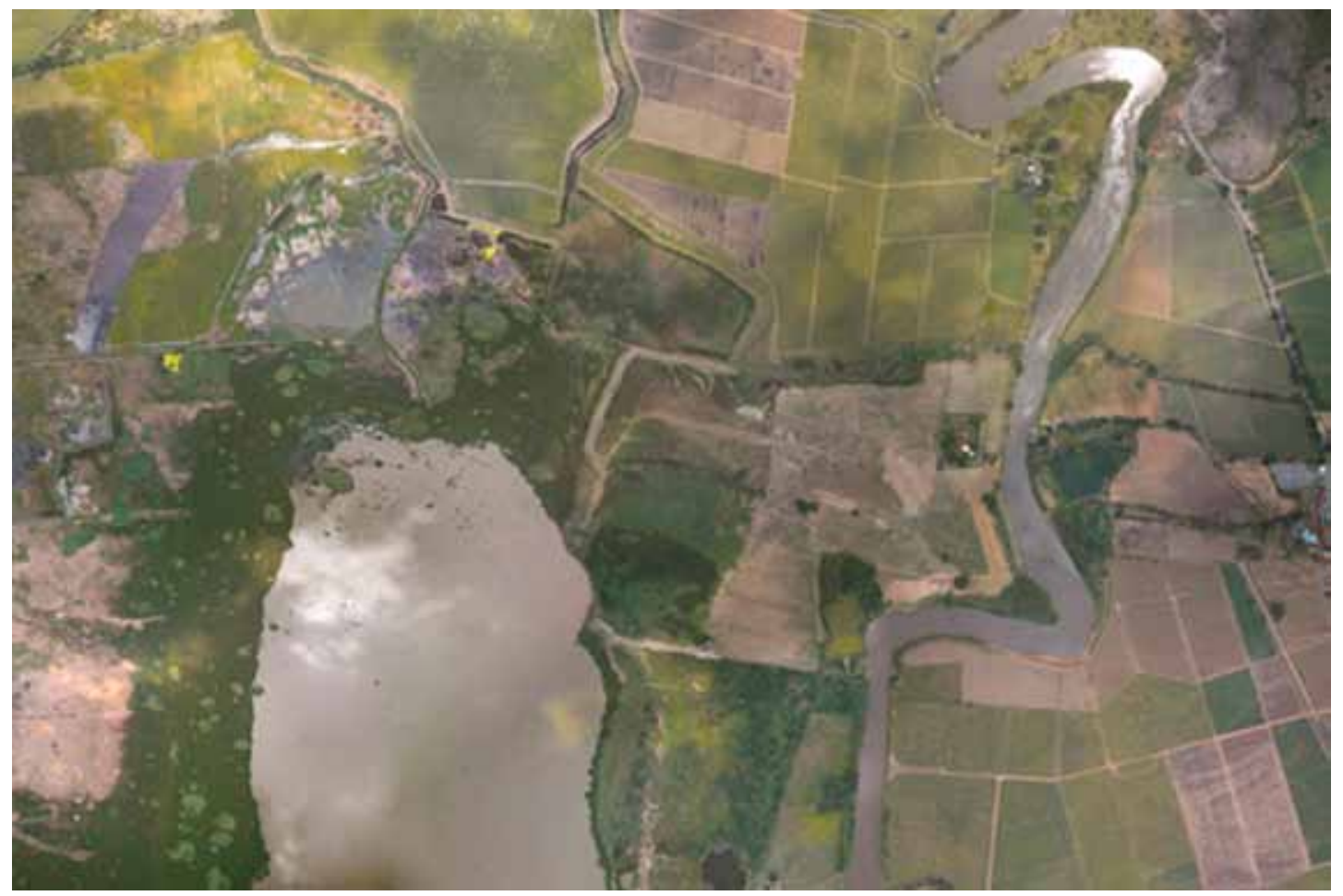

Figure 1. A section of the alluvial valley of the river Cauca with part of the Laguna de Sonso. Foto Rudolf, 2009. 
and birds. Although the once abundant turtles and mammals such as peccary which formerly roamed the area in large herds have largely vanished, in pre-Columbian times the richness of the fauna can hardly have failed to have been a constant attraction for human populations.

Conditions would not have been very different to those of the north coast of Colombia with its sequence of settled, pottery using populations going back to the fourth millennium B.C.; however, the valley is at a different altitude (an average of $1000 \mathrm{~m}$. above sea level) and therefore somewhat cooler. The importance of environments of this type with abundant water bodies has been emphasised by Gerardo Reichel-Dolmatoff (1986: 67-9) in his pioneering research on the northern coastal lowlands. He suggested that they were a source of such abundant protein that sedentary populations would be able to survive there without agriculture or with only a rudimentary form. In their discussion of Sauer's hypotheses on the early development of agriculture Piperno and Pearsall (1998: 18-21) emphasize his theory that "the edges of water bodies ... witnessed the earliest, permanent settlements of humans..." and that these disturbed, sunny habitats within the forest were particularly rich in a variety of nutritionally and technologically important plants (see also Piperno and Pearsall 1998: 74).

The Cauca valley has two wet seasons (AprilMay and October-December) separated by two dry seasons; the climax vegetation that once covered the area was semi-evergreen and deciduous woodland ("Bosque Seco Tropical" -see Diaz Merlano 2006). The maturity of many fruits, nuts, seeds and tubers is highly seasonal, another factor which, in the hypothesis of Sauer, would have favoured the early development of agriculture.

Hitherto, virtually all the information available for the pre-Ceramic period in this part of Colombia has come from the mountains bordering the Cauca valley. A number of excavations by different specialists have recovered evidence of a long sequence of occupations, starting shortly after the onset of the Holocene (Gnecco 2000, Herrera et al. 1992, Salgado 1989, Salgado y Gómez 2000, Cano et al. 2001, Herrera et al. 2011: 25-32). Small camp sites or settlements which, in some cases at least, appear to have been either semi-permanent or revisited over a long period of time (Salgado 1989: 89; Cardale Schrimpff et al. 2005: 31-2), were constructed, initially, in clearings in the humid, sub-tropical forest (Bosque Andino y Sub-Andino) of the mountain slopes. However, there is a gap in our knowledge of human occupation of a thousand years and more (p.e. Cardale Schrimpff 2005: 39; Cardale Schrimpff et al. 2005: chapter I, initial table; Aceituno and Loaiza 2006; Herrera et al. 2011: 32). The most recent dates for pre-Ceramic sites are in the third millennium B.C. and these later sites appear to be far less numerous than those known from earlier in the Holocene. This "archaeological silence" comes to an end about 700 B.C., by which time at least part of the area was inhabited by established farmers with sophisticated pottery. The period of silence is precisely when we would expect to find evidence for early Formative activity in the region, including an intensification of horticulture.

It is increasingly apparent from a number of research projects over the last twenty or thirty years that small-scale horticulture or at least plant-tending has a long history in the area but it is still far from clear how intensive this was at different periods during the pre-Ceramic and to what extent there was human impact on the environment (for a summary and discussion, see Aceituno 2002, Aceituno and Loaiza 2006; Aceituno and Lalinde 2011). At the Early Holocene sites of El Recreo and Sauzalito in the Calima region, studies of the phytoliths by Dolores Piperno suggest a forest environment with few clearings, an environment which had so far suffered little human impact. Studies from the same sites suggest that the characteristics of the soil, together with the phosphate levels, may reflect intermittent cultivation (summarised in Herrera et al. 1992; Cardale Schrimpff et al. 2005: 32-5). While there is no direct evidence for cultivated species, phytoliths of an unidentified squash or gourd were present as were those from a species of Marantaceae related to the arrowroot, which was later to become such an important food crop throughout the region. A surprising feature of these two sites is the quantity of charred nut shell fragments present, identified by Gaspar Morcote as belonging to a variety of avocado with small fruits (Cardale Schrimpff et al. 2005: Chapter I, note 24).

Little more than a thousand years after these sites were abandoned, there is evidence for maize cultivation nearby. A core from the hacienda Lusitania revealed maize pollen and evidence of probable human disturbance of the natural vegetation by the fourth or early fifth millennium B.C. (Monsalve, 1985: 40-44) while in second core, from the hacienda El Dorado in the same valley, maize pollen is dated to the sixth millennium B.C. (Monsalve, pers. com.; Cardale Schrimpff, ed., 2005: charts at beginning of Chapter I and at end of volume). There can be little doubt that horticulture, probably 
with a rather wide range of crops brought under cultivation, was firmly established in the area well before the development or arrival of the earliest Formative societies here.

Our knowledge of these populations, their subsistence patterns and their impact on their surroundings comes, as is usually the case, from the excavations of these sites. However, the current project has a rather different focus in that it concentrates directly on the environment in which these sites would once have been located. For this approach extensive areas of well-preserved ancient soil horizons are an essential pre-requisite, something which is almost impossible to find in the mountains where a long history of natural processes of erosion and of human activities has reduced the ancient horizons to small and discontinuous patches. These conditions are, however, provided by the floodplain of the upper river Cauca. Here too there is evidence of erosion, caused by the river Cauca itself and its tributaries but extensive areas of many of the early horizons are preserved by thick layers of alluvial sediment.

These factors were a prime motive for choosing the floodplain for this project. However, there was a certain amount of risk involved since it is an environment for which, previously, almost no information was available on either the environmental or the cultural history prior to about 2,500 B.C. and it was not inconceivable that this landscape of rivers, swamps and extensive seasonal floods had been avoided by earlier populations. In any event, the interaction between culture and the environment would have been very different here to the interaction in the surrounding mountains. At the same time, the respective advantages and disadvantages of each may have meant that the same population exploited both.

The project is designed to sample different regions of the valley with contrasting conditions: the area round the Laguna de Sonso and another at the northern extreme of the valley, centred on the municipios of La Unión and Toro where conditions are drier. So far research has concentrated on the Laguna de Sonso area, chosen for reasons which include the Laguna de Sonso itself, one of the few places in the valley which has proved to have good preservation of fossil pollen.

The first step was the construction of a map (by Pedro Botero) of the different physiographic landscapes in the Laguna de Sonso area (Cardale de Schrimpff et al. 2009, 2012). This was the based on the earliest available air photographs, before the landscape was modified so drastically for planting sugar cane. Working from this map, each of the landscapes was explored in turn. Evidence for a considerable number of Late Period sites was found in surface collections but for the location of Formative sites, Ilama and Yotoco, other tactics were necessary. These included the exploration of the banks of the river Cauca from a canoe where soil horizons at a greater depth were exposed; information provided by the local inhabitants was also invaluable.

In each of the physiographic landscapes a number of cores were taken with an Eijkelkamp auger for a preliminary study of the different soil horizons. These cores provided indispensable information on the environment and its changes in time within the different landscapes. They were also a valuable guide in the choice of points for the first two cores for the analysis of fossil pollen, Sonso 1 y 2 . Based on the information from these initial cores, four points were chosen for sampling with a mechanical augur which, in the deep alluvial soils, can penetrate to a far greater depth than the manual instrument. Taking advantage of the exceptionally dry conditions of the year 2010, two of these cores were located at points which would normally be covered by the waters of the lake. The other two were on or near the current natural dyke of the river Cauca.

A total of four cores for pollen analysis have been taken at different points on the lake bed, in all of which preservation is good. A fifth core, taken at the margin of a seasonal lake further south, proved to have extremely poor preservation. The lithology of these cores was studied by Pedro Botero. The results of the study of the pollen from three of the cores by Alejandra Betancourt and Juan Carlos Berrío are summarised here as are the phytolith studies by Neil Duncan; the full version of these studies forms part of the final report on this phase of the project recently presented to the FIAN (2012) and to be published shortly.

The two deep cores taken from the lake bed reached $1150 \mathrm{~cm}$ (near the CVC observation tower, known as the Torre de la CVC) and $850 \mathrm{~cm}$ respectively (Managua). A sample near the base of the first core is dated to the very early Holocene: 7.500-7.300 Cal. A.C. (BETA 279734). The date is for a point at $1031 \mathrm{~cm}$ below the current surface, in soils of a type of woodland growing in conditions that fluctuated between marsh and lake. This horizon had formed immediately above more than a metre of sand deposited by the river Guadalajara, possibly as a result of the great quantities of water released from the melting ice cap of the Central Cordillera 
at the end of the Pleistocene. The Torre de la CVC core would appear to offer the possibility of studying the history of the Laguna de Sonso throughout the Holocene.

The analysis of the pollen from the uppermost $500 \mathrm{~cm}$ of this core (Betancourt 2012) documents a long history of fluctuations in the level of water in the lake interpreted as the result of periods of greater and lesser humidity in the surrounding area Three very wet periods with a preponderance of aquatic plants such as Poaceae (Paspalum or water grass), Ludwigia, Typha and Spirogyra, between $490-410 \mathrm{~cm}, 380-330 \mathrm{~cm}$ and $250-230 \mathrm{~cm}$, alternate with four somewhat drier periods between $410-380 \mathrm{~cm}, 280-250 \mathrm{~cm}, 130-20 \mathrm{~cm}$ and from $20 \mathrm{~cm}$ to the surface. In four samples analysed from the earliest of these drier periods, pollen of a Cucurbitaceae has been identified. Two very dry periods were detected, one at a depth of $20 \mathrm{~cm}$ with a second period at between 210 and $220 \mathrm{~cm}$, represented by a total absence of aquatic vegetation. During the dry periods an extensive area was covered by marsh vegetation with a predominance of Cyperaceae; woodland in the area surrounding the lake became sparse.

In this core in general, taxa representative of moist, tropical forest (Bosque Subandino) is varied and represented by Mimosa, Arecaceae, Moraceae, Ficus, Alchornea, Acalipha, Protium, Euphorbiaceae, Fabaceae, Hedyosmum, Weinmannia, Phyllantus, Alnus, Miconia, Cecropia, Apocynaceae and Podocarpus; their numbers increase during the periods of greater humidity.

A succession of humid and less humid conditions is also documented in the "Sonso II" core taken at the southern end of the Laguna de Sonso in an area of marshland subject to flooding in the wet season (Betancourt 2012). This core is $2 \mathrm{~m}$. deep with a date of Cal. 1960-1750 B.C. (Beta
279733). Two contrasting situations were detected, the first between 200 and $80 \mathrm{~cm}$ with a predominance of Poaceae (floating grass meadows) and Convolvulaceae reflecting a greater expanse of open water; pollen from woodland species was represented by Hedyosmun, Weinmannia, Mimosa, Moraceae, Acalypha, Melastomataceae, Alnus, Podocarpus, Myrtaceae and Cyathea. For the second part of the history of the lake at this point, the area of open water had shrunk dramatically and been replaced by marshland with reedbeds of Cyperaceae. The appearance of vegetation characteristic of disturbed areas such as Ambrosia, Chenopodiaceae and Selaginella may indicate an increase in the rate of sedimentation at the edges of the lake and human impact on the environment.

In the "Sonso I" core (Lockett and Berrío 2012) found maize pollen at a depth of $213 \mathrm{~cm}$. No date is available currently but it is interesting to compare the date (Cal. 1960-1750 B.C.) for a similar depth in the Sonso II core. The total depth of this core is $655 \mathrm{~cm}$ but pollen analysis started at $550 \mathrm{~cm}$. when swamp replaced woodland that grew in the area for a period of about a thousand years. There is a calibrated date of c. 4000 B.C. (Beta 260035, Cal. 4250-3950) from sediments at between 625 and $640 \mathrm{~cm}$, some $15 \mathrm{~cm}$ above the start of the horizon with woodland soil. Three further samples, taken from within the woodland sediments $(640-625 \mathrm{~cm}$, $575-565 \mathrm{~cm}$, and $515-500 \mathrm{~cm}$ ) were analysed by Betancourt (2012) in hopes of discovering more about the type of woods that grew here. The hypothesis was that this would probably have consisted of species that resist long periods of flooding. Betancourt's analysis detected high proportions of aquatic and swamp vegetation and a small quantity of pollen from species from the Sub-Andean forest.

The pollen register indicates an environment that has varied between open vegetation consisting

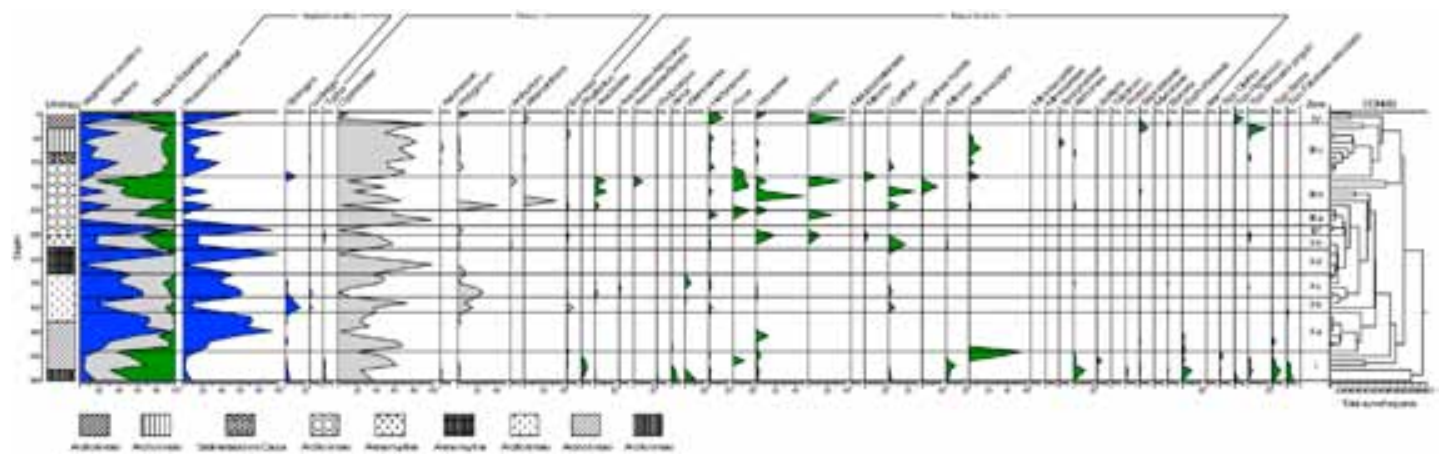

Figure 2. The Torre de la CVC core. 
predominantly of grasslands, possibly floating grass meadows (Poaceae) and of patches of dry forest on the foothills and mountain slopes near the lake. Once again, both the lithology and the pollen from the local vegetation (predominantly Cyperaceae) indicate alternating dry and wet periods. However, Lockett and Berrío (2012) note that, due to the considerable human impact in evidence in this core (from about $4 \mathrm{~m}$. in depth), it is difficult to be sure to what extent these fluctuations are due to climate change on a large scale and which are due to local conditions and anthropogenic factors.

This core is one of the very few places where it has been possible to detect what appears to have been a catastrophic volcanic event. The high proportion of sulphur in the analysis of the soil from the swamp horizon is interpreted by Botero as indicating an avalanche of volcanic debris that would have swept down the valley of the river Guadalajara from the Central Cordillera, burying the wood, damming the natural drainage pattern and forming a swamp. The upper section of the swamp is dated to c. 3000 B.C. (Beta 2360036, Cal. 3090-2380 B.C.) so the catastrophic event should have taken place at about this time or not long before.

Two further cores were obtained by the mechanical auger, each at a distance of some $700 \mathrm{~m}$. from the lake and close to the current banks of the river Cauca. These cores reached depths of $1050 \mathrm{y}$ $900 \mathrm{~cm}$ respectively. At the first site (Villalobín) soil studies indicate that the earliest horizon sampled was formed under the waters of a lake. The lake lasted for a considerable period of time, sufficient for the accumulation of 1 metre of clayey silt of a greyish blue colour. The lake gradually dried out and a swamp formed $(950-900 \mathrm{~cm})$ with sediments similar in texture but in colour a darker greyish blue as a result of a higher content of organic material due to an increase in the vegetation. A sample taken at $862 \mathrm{~cm}$, in a paleosol which developed immediately on top of the swamp, is dated to near or slightly before the start of the Holocene (BETA279735: Cal. 8550-8300 B.C.); it seems probable that the two lower horizons, lake and marsh, were formed during the period of transition between the end of the Pleistocene and the beginning of the Holocene when the alluvial valley would have been occupied by numerous lakes, fed by the waters from the melting ice in the Central Cordillera at this time.

Phytoliths from the second core, taken at the Yotoco Ferry site ("Barca de Yotoco"; Duncan 2012) provide evidence of agriculture early in the sequence
(Figure 3). "Ruffle-top" rondel forms diagnostic to maize were identified near the top of the sequence and below, and co-occur with a phytolith diagnostic of Cucurbita. The Cucurbita phytolith is too small to positively identify it as a domesticated squash. However, wild or domesticated, the co-occurrence of this squash phytolith with maize in the same sample is significant because it provides indirect evidence for early manipulation of squash in a region where the original domestication of C. moschata may have taken place (Nee 1990; Piperno and Pearsall 1998; Sanjur et al. 2002).

Phytolith preservation and recovery from the Barca de Yotoco samples are also sufficient for general qualitative interpretation of the local ecology of the area (Figure 4). Open habitat phytolith indicators are relatively abundant as are the arboreal and forest understory indicators. High numbers of grass phytoliths suggest influx from open habitat. Bulliform phytoliths, which are produced in the leaves of grasses in higher number in xeric or dry environments (Bremond et. Al 2005), are relatively well represented throughout the sequence, and also suggest phytolith influx from exposed, probably dry open habitats. Bulliform cells and their production may be useful indicators of water stress and transpiration (Sangster and Parry 1968; Andrejko and Cohen 1984; Bremond et al. 2005; Barboni, Bremond, and Bonnefille 2007). In general, bulliform cell production increases when plants are water stressed or subject to high amounts of transpiration. In this study, a high proportion of bulliform phytoliths might suggest dry periods or perhaps more open sun-exposed habitats where plants would be subject to more transpiration. Based on observations of bulliform production in desert, forest and tall grass savanna, and woodland environments, Bremond et al. (2005) observed a higher proportion of bulliform cells to grass phytoliths (minus elongate phytoliths types that may mimic sponge spicules) in more xeric environments.

In addition, in the Barca de Yotoco samples there are abundant arboreal and forest indicators, such as spinulose spheres of palms, nodular spheres from understory Marantaceae, and numerous sclerids from other woody eudicots that suggests influx from forested and closed habitats. Altogether, the phytolith data suggests a mixed-habitat landscape in the immediate vicinity of the Barca de Yotoco, with pockets of cleared areas that were perhaps for the purpose of agriculture. The presence of cultigens, maize and possibly cultivated squash, supports this conclusion. 


\begin{tabular}{|c|c|c|c|c|c|c|c|c|c|}
\hline PS\# & 4035 & 4036a,b & 4037 & 4038 & 4039 & 4040 & 4041 & 4042 & 4043 \\
\hline Site/Context & Barca de Ycto & Barca de Ycto & Barca de Ycto & Barca de Ycto & Barca de Ycto & Barca de Ycto & Barca de Ycto & Barca de Ycto & Barca de Ycto \\
\hline Depth & $306-312 \mathrm{AB}$ & $334-340 \mathrm{AB} 2$ & $500-508 \mathrm{Ab} 4$ & $542-550 \mathrm{Seq}$ & $576-584 \mathrm{Al}$ & $610-618 \mathrm{Ab} 5$ & 676-684 Ab6 & $701-709 \mathrm{Ab6}$ & $742-750 \mathrm{Ab} 6$ \\
\hline $\mathrm{ph}$ & 7.8 & 7.5 & 7.6 & 7.6 & 7.4 & 7.2 & 7.1 & 6.8 & 4.4 \\
\hline \multicolumn{10}{|l|}{ Phytoliths } \\
\hline \multicolumn{10}{|l|}{ Arbóreal and Forest Understory } \\
\hline Arecaceae spinulose sphere & 57 & 33 & 3 & 7 & 25 & 49 & 21 & 50 & 12 \\
\hline Marantaceae/Bombacaceae nodular spere & 25 & 23 & 2 & 12 & 22 & 26 & 14 & 37 & 20 \\
\hline Sclerid - elongate & 8 & 1 & 30 & & 17 & 15 & 10 & 16 & 24 \\
\hline Sclerid - faceted & 1 & 21 & 8 & 28 & 14 & 33 & 47 & 19 & 32 \\
\hline Sclerid Faceted hemisphere & & 15 & & & & & & & 15 \\
\hline \multicolumn{10}{|l|}{ Open Habitat } \\
\hline \multicolumn{10}{|l|}{ Panicoid Grasses } \\
\hline Bilobate & 48 & 33 & 4 & 5 & 56 & 30 & 7 & 23 & 8 \\
\hline Crenate & 3 & 5 & & & 4 & 2 & 2 & 1 & 1 \\
\hline 3-lobed & 2 & 1 & & & & & & & 1 \\
\hline Cross Var 5/6 & & & & & 2 & & & & 1 \\
\hline Cross Var 1 - Zea mays and some Panicoid & & & & & & & & 1 & \\
\hline Unilobate & 15 & 3 & 1 & 3 & 7 & 2 & 3 & 9 & 1 \\
\hline Complex topped Panicoid short cells & 36 & 40 & 6 & 10 & 35 & 29 & 16 & 24 & 15 \\
\hline \multicolumn{10}{|l|}{ Festucoid/Pooid Grasses } \\
\hline square/rectangular & & 6 & & & 3 & 1 & 2 & 3 & \\
\hline \multicolumn{10}{|l|}{ Chloridoid Grasses } \\
\hline saddles & 7 & 8 & & & 8 & 3 & 1 & 10 & 3 \\
\hline \multicolumn{10}{|l|}{ Forest Margin } \\
\hline \multicolumn{10}{|l|}{ Bambusoid Grasses } \\
\hline Bambusoideae & & 10 & 1 & 1 & 5 & & 1 & 3 & 4 \\
\hline Guadua/Chusquea tvpes & 4 & 2 & & & 4 & 4 & & 7 & 2 \\
\hline Olyreae tribe $\operatorname{Var} 3 / 8$ cross/bilobate & 3 & & & & & 1 & & & \\
\hline Pharus type & 1 & & & & & & & & \\
\hline \multicolumn{10}{|l|}{ Bambusoideae and Arundinoideae } \\
\hline saddles and elliptoid & & & & & 2 & 4 & & 1 & \\
\hline \multicolumn{10}{|l|}{ Redundant Poaceae (Outside Sum) } \\
\hline Bulliform & 33 & 62 & 16 & 38 & 33 & 35 & 33 & 44 & 40 \\
\hline Redundant short cells & 18 & 8 & & 3 & 8 & & 3 & 14 & 8 \\
\hline Epidermal long cells & 15 & 34 & 1 & 16 & 29 & 25 & 18 & 23 & 15 \\
\hline Unicellular hair & & & & & 1 & & & & \\
\hline \multicolumn{10}{|l|}{ Wet Indicators } \\
\hline Cyperaceae Carex seed epidermis & & 1 & & & & 1 & & & \\
\hline Cyperaceae Scirpus seed epidermis & & & & & & 3 & & & \\
\hline \multicolumn{10}{|l|}{ Cultivated } \\
\hline Zea spp. ruffle top & & 1 & & & 1 & 1 & & & \\
\hline Cucurbita sp. & & & & & & 1 & & & \\
\hline Total Phytoliths & 210 & 203 & 55 & 66 & 205 & 205 & 124 & 204 & 139 \\
\hline Non-diagnostic Burned Phytoliths & R-M & $\mathrm{R}$ & $\mathrm{R}$ & $\mathrm{M}$ & $\mathrm{R}$ & $\mathrm{R}$ & $\mathrm{M}$ & $\mathrm{M}$ & $\mathrm{M}$ \\
\hline Diatoms & & 3 & & 1 & 1 & & & 6 & 7 \\
\hline Sponqe Spicules & & 3 & & 6 & 4 & 7 & 11 & 11 & \\
\hline
\end{tabular}

Figure 3. Phytoliths from the Yotoco Ferry core (Barca de Yotoco).

The four radiocarbon dates available for this sequence are, in some cases, problematic. The uppermost date from an $\mathrm{AB}$ at a depth of $210-220 \mathrm{~cm}$ (Beta 318016, Cal. 7700-7700; 7680-7580 B.C.) is disconcerting since it comes from a point immediately below the late Formative horizon (Yotoco and possibly, Ilama) which cannot be older than early in the first millennium B.C. The date for this $\mathrm{AB}$ was of particular interest to us since, if this horizon precedes the late Formative horizon not only physically but also chronologically, it falls precisely within the period of "archaeological silence". The same horizon is preserved at a number of the points sampled and only additional dates can resolve the question of whether the date is a chance misfit or represents some sort of upheaval at this time, sufficiently catastrophic to result in the mixing of materials, a situation which might, in turn, explain the absence, so far, of archaeological sites at this time.
A second date (Beta 318014, Cal. 1783017770 B.C.; $610-618 \mathrm{~cm}$ ) is also a misfit: the lithology has been interpreted as a sequence of $\mathrm{ABs}$ and incipient Abs but may, perhaps, represent a more "catastrophic" mixing of sediments of different origins or, perhaps, be the result of upwellings of deep groundwater such as those documented for the Laguna de Sonso. Given the location from where the core was taken, on the banks of a highly dynamic, meandering river, the possibility of its gouging out older sediments upstream and depositing them in inverse sequence downstream must always be taken into account (Darden Hood, Beta, Personal communication, May 2012).

The other two dates (Beta 318015, Cal. 56105590 B.C., $334-340 \mathrm{~cm}$ and Beta 318013, Cal. $6230-6060,742-750 \mathrm{~cm}$ ) are not far out of line with dates from other sites. The first of these, with maize phytoliths in the sixth millennium B.C., although very early for this cereal, is in agreement 


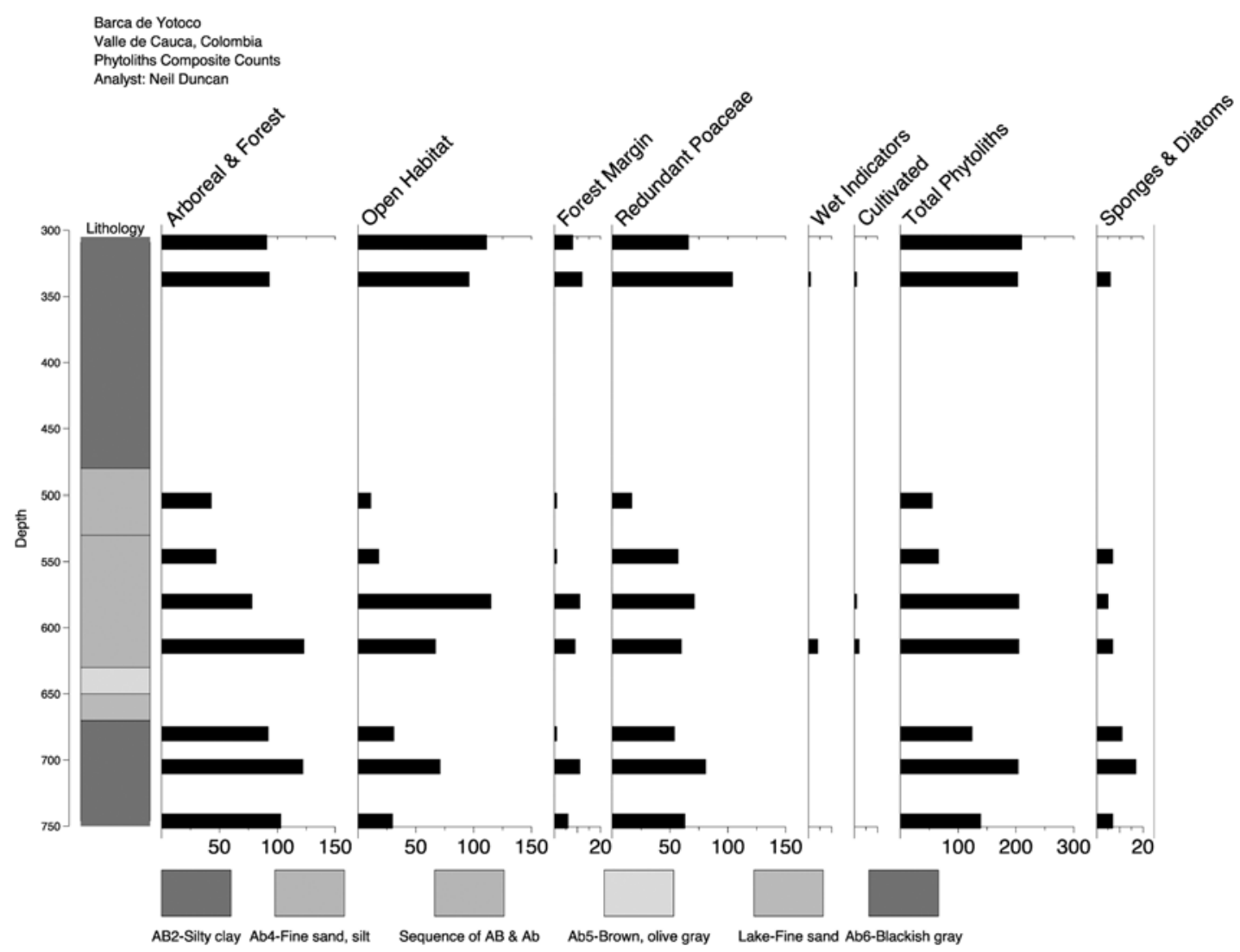

Figure 4. Phytolith Graph by Count from the Yotoco Ferry core (Barca de Yotoco).

with the sixth millennium date already mentioned for pollen of this cereal at the Hacienda El Dorado and there is a similar date for the Middle Cauca site of El Jasmín (Aceituno 2002: 104). However, further evidence is needed, preferably from closed contexts, before we can be comfortably sure that it was already under cultivation at this time. The lowest date, from a sample in a marshy paleosol, is reasonably close in time to the date for near the base of a similar paleosol from the neighbouring site of Villalobin (Beta 279735, 8550-8300 B.C., $862 \mathrm{~cm}$.). The presence of burnt phytoliths associated with this date suggests that there may already have been human impact on the environment in the Early Holocene, towards the end of the ninth millennium B.C.

In addition to our fieldwork on the valley floor, we reconnoitred a number of points where the mountains of the Western Cordillera meet the alluvial plain, concentrating especially on places where streams and small rivers and emerge onto the flood plain. Here, although close to the Cauca and all that this river had to offer, clean water would have been available permanently and the difference in altitude of a few metres would have meant that settlements would have been safe from the floods. It is in situations with these characteristics that early sites, often preceramic, have been found in places such as the valley of the river Zana on the north coast of Peru and the central Pacific region of Panamá (Piperno and Pearsall 1998: 208-9). In the area of our research, these locations often proved to have been taken advantage of by the later Formative populations for both settlements and cultivation; however we were unable to find sherds, stone tools or other elements of material culture earlier that the Ilama period. On the other hand we did find buried soils $\left(\mathrm{A}_{\mathrm{b}} \mathrm{s}\right)$ at considerable depths below these settlements. Preliminary and tentative interpretations of these soils suggest that they were formed before the dry period for which there appears to be evidence in the river bank exposures. 


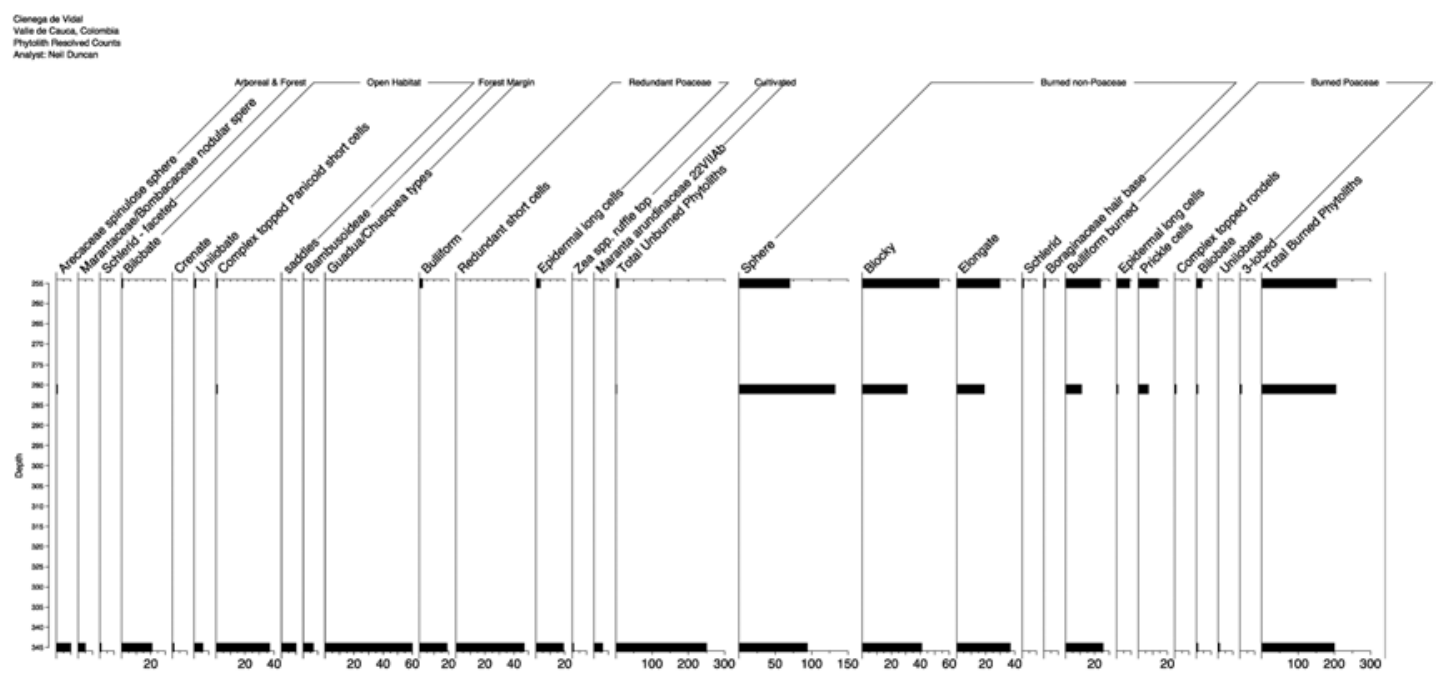

Figure 5. Phytoliths counts of unburned and burned phytoliths from Cienega de Vidal.

This dry period started at a point in time still to be defined but probably near the beginning of the $2^{\text {nd }}$ millennium B.C. and may have ended shortly before the onset of the Ilama period.

A particularly attractive site, at the foot of the Cordillera, is the Ciénega de Vidal where a narrow strip of land between the mountains and a seasonal lake provided excellent conditions for both settlements and cultivation. There is abundant evidence for human activities here during the Late Period (Sonso) and the results of the study of phytoliths from a small excavation provide further support for the presence of early human activities. These samples contain unusually high numbers of burned phytoliths that likely indicates intentional burning of vegetation (Figure 5). Burned phytoliths are often unchanged morphologically and can be identified to group or type, such as Poaceae short cells, bulliforms, epidermal long cells, hair or "prickle"cells, rondels and lobed forms. Where fires are not part of the natural ecology, such as most tropical forests, human induced burning may be easier to infer (Piperno 2006: 135-138). ${ }^{1}$ Burned phytoliths have been used to infer or corroborate evidence of human landscape modification and/or agricultural practices (Piperno 1985, 1994; Piperno and Pearsall 1998: 280-282; Boyd 2002; Kealhofer 1996; Bush et al. 2007; Pohl et al. 2007; and others). Burned or carbonized phytoliths have unique characteristics and may undergo morphological changes associated with extreme heat (Parr 2006). Often, however, burned phytolith morphology remains unchanged. In the
Cienega de Vidal samples, burned Poaceae phytoliths were easily recognizable, but other phytoliths from probable eudicot plants are represented as burned spheres, blocky and elongate forms, sclerids, and one burned silicified hair cell base from Boraginaceae. Cultivated plants, maize and arrowroot, are only evident in the lower sample $(330-360 \mathrm{~cm} \mathrm{~b} / \mathrm{s}$; \#4050) and these phytoliths were not burned.

In the upper two samples from Cienega de Vidal, unburned diagnostic phytoliths were relatively rare and would not have provided significant numbers of diagnostic phytoliths to reach a standard count of 200. Therefore, we took the unusual step of counting burned phytoliths to a total of 200 , while also tallying unburned phytoliths in a separate sum. For consistency, this was also done for the third sample (330-360 B; \#4050), but unlike the other two samples, this sample contained sufficient numbers of unburned diagnostic phytoliths to exceed 200. In this third sample, burned phytoliths are well represented, but outnumbered by unburned diagnostic phytoliths. This sample provides the clearest indication of the local environment. Grasses are abundant and arboreal and forest understory types are slightly less, but include palms and nodular spheres from Marantaceae and/or Bombacaceae. Forest margin grasses in the Bambusoideae subfamily are well represented, which, together with a dominance of grass types in this sample suggests a more open habitat with minor forest and understory contribution. This sample also contained evidence of cultivated plants, a single maize rondel 
and six seed phytoliths produced in arrowroot. These cultivated taxa likely correspond to cleared areas for agriculture and the burned phytoliths in this sample most likely represent land-clearing practices associated with agriculture some time before 2480-2290 Cal. B.C. In this lowest sample $(330-360 \mathrm{~cm} \mathrm{~b} / \mathrm{s})$, it is interesting that among the non-burned taxa, open habitat indicators are well represented, however in the same sample, burned phytoliths from non-Poaceae types are much more abundant than burned Poaceae types. If the landscape was being managed with fire, the high proportion of non-burned open habitat indicators compared to burned non-Poaceae types suggests that open habitats may have been expanding by burning additional forest taxa or that secondary forest was being cleared from an already open habitat with abundant grasses. These activities are in evidence again in the next highest stratum $(267-295 \mathrm{~cm} \mathrm{~b} / \mathrm{s})$ where non-Poaceae types are better represented than burned Poaceae, although the deposition of non-burned phytoliths was very low. There appears to be a shift, however, in the highest stratum (243-267 cm b/s), where burned Poaceae phytoliths are much more abundant.

It is difficult to asses the intensity of burning required to produce such high numbers of burned phytoliths in the upper two samples, but burning was sustained and significant enough to result in unusually high numbers of burned phytoliths in the combined $52 \mathrm{~cm}$ strata. Unburned phytoliths are too sparse in these samples to interpret the vegetative makeup of the local environment, but it is possible that the intensive burning above a stratum containing cultivated plants represents an expansion or management of open habitats by burning or perhaps a prolonged episode of clearing following a period of fallow. The abundance of non-Poaceae burned phytoliths may represent secondary or successional eudicot taxa, such as shrubs and small trees, or forest margins under active clearing.

It is interesting -and sobering- to find that the horizon immediately above the most recent of the ones with burnt phytoliths contains increasing quantities of rubble, accumulated from the mountain slopes behind. While this may simply be the result of a very dry period when there was little vegetation on the slopes to protect them, equally the vegetation may have been destroyed by the fires, leaving the slopes bare and open to erosion with every tropical downpour.
In summary, this multi-proxy study suggests that human populations were occupying or, at least, exploiting, the alluvial valley of the upper Cauca river for thousands of years starting, probably, in the Early Holocene. In view of its exceptional riches in terms of fish and game, it seems not unlikely that bands of hunters would have been attracted to the valley in much earlier times, possibly in the late Pleistocene when their influence on the environment would still have been negligible and very difficult to detect. The earliest date associated (still tentatively) with cultigens (maize phytoliths) is for the mid sixth millennium B.C. However, if we are correct in interpreting the presence of burnt phytoliths as evidence of intentional fires started for clearing the vegetation for the preparation of garden plots, evidence for human impact on the environment goes back as far as the early part of the seventh millennium.

It seems probable that these populations would have exploited the basins bordering the rivers and the gently sloping area between the basins and the natural dykes that form on the river banks. Although under water for part of the year, in the dry seasons these areas could be used for growing crops such as maize and squash which mature in a few months. Those plants which need more time to mature and drier conditions, such as arrowroot (Maranta arundinacea), would have been cultivated on the slightly higher ground of the piedmont. In later years, at least, the houses would have been built on the slightly higher ground provided by the natural dykes as well as on the colluvialalluvial fans of the piedmont. It seems likely that, in some places at least, the problem of extensive seasonal flooding was solved by constructing these dwellings on raised platforms like the houses built today by indigenous groups in the neighbouring Chocó.

Undoubtedly these groups would have seen, or generated, profound changes in their economic base with important advances in their agricultural techniques and in the range of plants brought under cultivation long before the onset of the Formative period. They would have had to learn to live with extensive annual floods when much of their time would have been spent in a canoe. With the passing of the generations they would also have had to adapt to periodic changes in the climate and vegetation with oscillations between very wet and very dry conditions, changes that would have had 
profound effects on the range of crops that could be grown successfully. Although evidence is hard to recover in the valley these people, like their neighbours in the mountains, would undoubtedly have suffered periodic eruptions and ash fall from the volcanoes of the Central Cordillera. For the valley-dwellers there was the additional hazard of catastrophes caused by torrential flows of ash and other materials brought down by the rivers rising in these mountains, such as the flow that appears to have killed the forest at Sonso I.

\section{Acknowledgements}

This research was funded principally by the Fundación de Investigaciones Arqueológicas Nacionales (FIAN), Banco de la República without whose support this project could never have been carried out. Valuable contributions came from a number of other sources and we are particularly grateful to the Pro Calima Foundation for Archaeological Research (Switzerland and Bogotá), to Orlando Rangel and the Instituto de Ciencias Naturales of the Universidad Nacional in Bogota for permitting Alejandra Betancourt to use their facilities, to the Department of Geography of the University of Leicester, and to Deborah Pearsall and the Paleoethnobotany Laboratory of the University of Missouri for their collaboration with the phytolith study. We also owe a debt of gratitude to all the many institutions and individuals who have helped us in the Cauca valley, the CVC (Corporación Autónoma del Valle del Cauca), OSSO (Observatorio Sísmico del Suroccidente) and, particularly, INCIVA (Instituto para la Investigación y la Preservación del Patrimonio Cultural y Natural del Valle del Cauca) and to Robert Peck and his collaborators at ASOYOTOCO, an organisation dedicated to preserving the environment and rural societies in the Laguna de Sonso region.

\section{References Cited}

Aceituno, F.J.

2002 Interacciones fitoculturales en el Cauca Medio durante el Holoceno temprano y medio. Arqueología del Área Intermedia, No. 4: 89-113. Instituto Colombiano de Antropología e Historia-Sociedad Colombiana de Arqueología. Bogotá.

Aceituno, F. y N. Loaiza

2006 Una Aproximación Ecológica al Poblamiento del Cauca Medio entre el Pleistoceno Final y el Holoceno Medio. In Cambios Ambientales en Perspectiva Histórica. Ecología Histórica y Cultura Ambiental, eds. C. López and M. Cano, Vol. II, 42-55. Pereira: Grupo Gestión de Cultura y Educación Ambiental, Facultad de Ciencias Ambientales, Universidad Tecnológica de Pereira.

Aceituno, F. and V. Lalinde

2011 Residuos de almidones y el uso de plantas durante el holoceno medio en el Cauca medio (Colombia). Caldasia 33 (1), 1-20.

Andrejko, M.J. and A.D. Cohen

1984 Scanning Electron Microscopy of Silicophytoliths from the Okefenokee Swamp-Marsh Complex. In The Okefenokee Swamp: Its Natural History, Geology and Geochemistry edited by A.D. Cohen, D.J. Casagrande, M.J.Andrejko and G.R.Best. Wetland Surveys, Los Alamos, NM.

Barboni, D.; L. Bremond and R. Bonnefille

2007 Comparative Study of Modern Phytolith Assemblages from Inter-Tropical Africa. Palaeogeography, Palaeoclimatology, Palaeoecology 246 (2-4): 454-470.

Betancourt, A.

2012 Análisis Palinológico de la Laguna de Sonso. Informe preliminar Núcleo Torre CVC. Informe Núcleo Sonso II. Anexo III. In Cardale de Schrimpff et al. Ocupaciones humanas y el medio ambiente en el valle del río Cauca (Sector Laguna de Sonso) 8.000-0 A.C. Second phase.
Final Report. Fundación de Investigaciones Arqueológicas Nacionales del Banco de la República-FIAN.

Boyd, M.

2002 Identification of Anthropogenic Burning in the Paleoecological Record of the Northern Prairies: A New Approach. Annals of the Association of American Geographers 92 (3): 471-487.

Bray, W.

2012 Las excavaciones arqueológicas en los sitios de Moralba y Barca de Yotoco. Anexo I. In: Cardale de Schrimpff et al. Ocupaciones humanas y el medio ambiente en el valle del río Cauca (Sector Departamento del Valle) 8.000-0 a.C. Second Phase. Final Report. Fundación de Investigaciones Arqueológicas Nacionales del Banco de la República-FIAN. 2012.

Bremond, L.; A. Alexandre; O. Peyron and J. Guiot 2005 Grass Water Stress Estimated from Phytoliths in West Africa. Journal of Biogeography 32 (2): 311-327.

Bush, M. B.; M. R. Silman; M. B. De Toledo; C. Listopad; W. D. Gosling; C. Williams; P. E. De Oliveira and C. Krisel

2007 Holocene Fire and Occupation in Amazonia: Records from Two Lake Districts. Philosophical Transactions of the Royal Society B: Biological Sciences 362 (1478): 209-218.

Cano, M.; C. López and J.A. Realpe

2001 Diez mil años de huellas culturales en los suelos del eje cafetero. In Suelos del Eje Cafetero. Proyecto U.T.P., Facultad de Ciencias Ambientales-GTZ, Cooperación Alemana al Desarrollo. Pereira.

Cardale de Schrimpff, M.

1996 Caminos prehispánicos en Calima. El estudio de caminos precolombinos de la cuenca del alto río Calima, cordillera occidental, valle del Cauca. FIAN, Banco de la República, Bogotá. 
2005 The People of the Ilama Period. In: Cardale de Schrimpff ed., Calima and Malagana. Art and Archaeology in Southwestern Colombia. Pro Calima Foundation. Lausanne. Cardale De Schrimpff, M.; P. Botero; A. M. Groot; A. Betancourt y J. C. Berrío

2009 El Hombre y el medio ambiente en el valle del río Cauca (Sector Departamento del Valle) 8.000-0 a.C. Final Report. First Phase. Fundación de Investigaciones Arqueológicas Nacionales del Banco de la República-FIAN.

Cardale De Schrimpff, M.; P. Botero; A.M. Groot; A. Betancourt J.C. Berrío y N. Duncan

2012 Ocupaciones humanas y el medio ambiente en el valle del río Cauca (Sector Departamento del Valle) 8.000-0 A.C. Second phase. Final Report. Fundación de Investigaciones Arqueológicas Nacionales del Banco de la República-FIAN.

Díaz Merlano, J.M.

2006 Bosque Seco Tropical. Banco del Occidente, Cali.

Duncan, N.A. and D.M. Pearsall

2012 Preliminary Report on Phytoliths from Sediment Samples from the Cauca Valley, Colombia. Anexo IV in: Cardale de Schrimpff et al. Ocupaciones humanas y el medio ambiente en el valle del río Cauca (sector laguna de Sonso) 8.000-0 A.C. Second phase. Final Report. Fundación de Investigaciones Arqueológicas Nacionales del Banco de la República-FIAN.

Gnecco, C.

2000 Ocupación temprana de bosques tropicales de montaña. Editorial Universidad del Cauca. Popayán.

Herrera, L.; M.C. Moreno and O. Peña

2011 La historia muy antigua del municipio de Palestina (Caldas). Proyecto de Rescate y Monitoreo Arqueológico del Aeropuerto del Café. Centro de Museos-Universidad de Caldas, Asociación Aeropuerto del Café (205-2011).

Herrera, L.; M. Cardale De Schrimpff; W. Bray and P. Botero 1992 Nuevas fechas de radiocarbono para el Precerámico en la cordillera occidental de Colombia. En: O. OrtizTroncoso y Thomas van der Hammen (ed.). Archaeology and Environment in Latin America, pp. 145-163. Proceedings of a symposium held at the 46th International Congress of Americanists, Amsterdam, July 4-8, 1988. Instituut voor pre-en protohistorische Archeologie Albert Eggers van Giffen (IPP), Universiteit van Amsterdam.

Kealhofer, L.

1996 The Human Environment During the Terminal Pleistocene and Holocene in Northeastern Thailand: Phytolith Evidence from Lake Kumphawapi. Asian Perspectives 35 (2): 229-254.

Lockett, T. and J. C. Berrío

2012 Paleoenvironmental changes since the mid Holocene at Lake Sonso in the Cauca valley, Colombia. Anexo II in: Cardale de Schrimpff et al. Ocupaciones humanas y el medio ambiente en el valle del río Cauca (sector laguna de Sonso) 8.000-0 A.C. Second Phase. Final Report. Fundación de Investigaciones Arqueológicas Nacionales del Banco de la República-FIAN.
Monsalve, J.

1985 A pollen core from the Hacienda Lusitania. Pro Calima, Archäologisches Projekt im westlichen Kolumbien/ Südamerika No. 4, 40-44.

Nee, $M$.

1990 The Domestication of Cucurbita (Cucurbitaceae). Economic Botany 3 Supplement: 56-68.

Parr, J.E.

2006 Effect of Fire on Phytolith Coloration. Geoarchaeology 21 (2): 171-185.

Piperno, D.R.

1985 Phytolith Records from Prehistoric Agriculture Fields in the Calima Region, Colombia. Pro Calima 4: 37-40.

2006 Phytoliths: A Comprehensive Guide for Archaeologists and Paleoecologists. AltaMira Press, Oxford.

Piperno, D.R. and D.M. Pearsall

1998 The origins of Agriculture in the Lowland Neotropics. Academic Press. San Diego, California.

Pohl, M.E.D.; D.R. Piperno; K.O. Pope and J. G. Jones

2007 Microfossil Evidence for Pre-Columbian Maize Dispersals in the Neotropics from San Andres, Tabasco, Mexico. Proceedings of the National Academy of Sciences 104 (16): 6870-6875.

Reichel-Dolmatoff, G.

1986 Arqueología de Colombia. Un texto introductorio. Fundación Segunda Expedición Botánica. Bogotá.

Rodríguez, C.A.

2002 El Valle del Cauca Prehispánico. Procesos socioculturales antiguos en las regiones geohistóricas de Alto y Medio Cauca y la Costa Pacífica colombo-ecuatoriana. Departamento de Historia, Facultad de Humanidades, Universidad del ValleFundación Taraxacum, Washington D.C. Cali.

Salgado, $\mathrm{H}$.

1989 Medio ambiente y asentamientos prehispánicos en el Calima medio. INCIVA. Cali.

Salgado, H. and A.N. Gómez

2000 Pautas de asentamientos prehispánicos en CajamarcaTolima. FIAN, Banco de la República-Universidad del Tolima.

Sandoval, M.C. and C.A. Ramírez

2005 El río Cauca en su valle alto. Un aporte al conocimiento de uno de los ríos más importantes de Colombia. Corporación Autónoma Regional del Valle del Cauca, CVC-Programa Editorial Universidad del Valle. Cali.

Sangster, A.G. and D.W. Parry

1968 Some Factors in Relation to Bulliform Cell Silicification in the Grass Leaf. Annals of Botany 33: 315-323.

Sanjur, O.I.; D.R. Piperno; T.C. Andres and L. Wessel-Beaver 2002 Phylogenetic Relationships among Domesticated and Wild Species of Cucurbita (Cucurbitaceae) Inferred from a Mitochondrial Gene: Implications for Crop Plant Evolution and Areas of Origin. Proceedings of the National Academy of Sciences of the United States of America 99 (1): 535-540.

\section{Note}

1 Juan Adarve, a forestry specialist with the Instituto Vallecaucano de Investigaciones Científicas (INCIVA), who has worked for many years in the area, considers natural forest fires to be unlikely in this environment (Personal communication, May 2011). 